\title{
Cotta, Maurizio and Russo, Federico (2020). Research handbook on political representation
}

\author{
Cheltenham, UK; Northampton, MA, USA: Edward Elgar. 368 S., \\ ISBN: 978-1-78897-708-1 175.-
}

\section{Martin Gross}

Published online: 14 December 2021

(C) The Author(s) 2021

Who is represented by whom? What are the social characteristics of representatives? And how should representatives represent citizens' varying and changing needs and preferences? These are three of many fundamental questions regarding political representation, which lies at the heart of contemporary models of democracy. The 27 contributions in Maurizio Cotta's and Federico Russo's edited "Research Handbook on Political Representation" provide answers to these questions - and to many, many more!

The edited volume consists of four sections. The first two sections lay the theoretical foundation for the more empirically oriented contributions in sections III and IV. The six contributions in section I conceptually and theoretically analyse the meaning, definition, application of, and challenges for political representation principles. Russo and Cotta set the stage with an historical overview on the early distinction and later "marriage" between representation and democracy (p. 6). They highlight that particularly the wide gap between normative theorists and empirical scholars became smaller with the seminal work by Hanna Pitkin ("The Concept of Representation", Berkeley, CA, University of California Press, 1967) and her distinction between formalistic, descriptive, symbolic, and substantive representation. Other authors in this section also built their arguments on Pitkin's work but take different routes to emphasise various specific aspects of political representation in democracies (particularly see the contributions by Mark B. Brown and Simon Tormey, respectively).

The six contributions in section II deal with historical and contemporary models of political representation, ranging from individual over party-based to technocratic

Dr. Martin Gross $(\bowtie)$

Geschwister-Scholl-Institut für Politikwissenschaft, Ludwigs-Maximilians-Universität München,

Oettingenstraße 67, 80538 Munich, Germany

E-Mail: martin.gross@gsi.uni-muenchen.de 
forms of representation. Especially the latter contribution on "Technocratic representation" by Daniele Caramani enriches the debate on (perceived) representational deficits by current political elites. He insightfully and thought-provokingly discusses four distinctive dimensions of technocratic representation: (a) who acts; (b) on behalf of whom; (c) what is the link between actors and those on whose behalf they act; and (d) how are actions determined? Considering the resounding calls for 'expert governments' or 'technocratic cabinets' in some countries, depending on one own's point of view, Caramani's discussion of technocratic representation can be interpreted as a call for, or as a warning signal against such governments: technocratic representation necessarily will have a lower degree of descriptive representation than other forms of representation because experts will be even more elitist than the current political elite. Furthermore, because "[t]echnocratic representation is about the common interest" (p. 138), specific parts of a society, e.g., minorities, and their preferences might be overruled by the "strive" for "a holistic (anti-pluralist) representation" (p. 138; emphasis in original). Last but not least, technocratic representation is non-democratic in the sense that experts' long-term orientation towards the common interest leads them to not make any electoral promises in the short term, thus preventing voters to hold them accountable.

Even though the contributions in section II enrich our conceptual and theoretical understanding of political representation in current democracies, it is the contribution by Maurizio Cotta on "Representation in authoritarian regimes" that stands out in this section. He calls for more theoretical and empirical work on the following important questions (p. 153): "Why do non-democratic regimes incorporate the typical institutions of representative democracy? What is their purpose? Are these institutions instruments of representation or what else? And what are the consequences for the regime of having them instead of doing without them?" His thoughts on potential answers to these questions can serve as a starting point for a new strand of research on political representation in non-democratic, authoritarian regimes.

Section III also comprises six contributions and focuses on the institutional aspects of representation. Here, questions related to the effects of electoral systems, gender, and ethnic backgrounds on representation are at the centre of various contributions. The contribution by Miriam Hänni and Thomas Saalfeld on "Ethnic minorities and representation" is one of the highlights in the edited volume. The authors present new data on the representation of autochthonous ethnic minorities in $12 \mathrm{Eu}-$ ropean democracies, demonstrating large variations in the descriptive representation of ethnic minorities in democratic parliaments. Whereas some ethnic minorities are overrepresented to a large extent (e.g., the Welsh in Great Britain, or the Swedes in Finland), others are not represented at all in national parliaments (e.g., Ukrainians in Estonia, or some indigenous minorities in Ecuador or Paraguay). Their conclusion that one of "the most straightforward mechanisms to deliberately ensure the representation of ethnic minorities are reserved seats and quotas" (p. 227) connects very well with Mona Lena Krook's contribution on "Electoral quotas and group representation".

Furthermore, the contribution by Lori Thorlakson on "Territorial and multilevel representation" stands out. Thorlakson emphasises that "[i]n the modern state, we usually understand representation in territorial terms" (p. 171). Contrasting territo- 
rial representation from functional representation and combining these insights with the literature on federalism, this chapter highlights the importance of multilevel systems with decentralised decision-making procedures to bring "representation closer to the people" by enhancing "representation of territorial units" (p. 172). Yet, Thorlakson rightfully highlights one severe drawback of territorial representation-it complicates voters' ability to hold politicians accountable for their actions. In her words " $[w]$ hatever institutional design structures territorial representation, it creates complexity, by introducing compounded representation in the state, with multiple principal-agent relationships" (p. 180). Thorlakson ends her contribution with this notion, but several important (and provocative) follow-up questions arise: If territorial representation adds complexity to multilevel political systems why not get rid of it and centralize political decision-making? Recent research shows that even in centralized, unitarist political systems with single-party governments citizens have problems in correctly identifying which political actors are responsible for which policy actions - and things look worse in decentralized, federal systems with varying degrees of shared- and self-rule between different political layers. Furthermore, does an increased territorial representation and the territorialisation of politics through parties have detrimental effects of society as a whole? In other words, does the promotion of "devolution or decentralization of the state" really "deliver stronger formal channels of territorial representation" (p. 178), or could this be also one of the reasons for an increase in separatist movements striving for independence, like in Catalonia or Scotland?

The last, and weakest, section IV comprises nine contributions on "Representation at work: outputs and outcomes". All nine contributions pick a specific component of political representation in democratic systems, summarize the state of the art, and discuss promises and pitfalls in studying pledge fulfilment, policy congruence, responsiveness, or candidate selection. The strength of these contributions lies in their concise manner of presenting important empirical studies in the scholarly field of political representation research. This is, however, also the main weakness: the authors can only scratch on the surface of these components of political representation without going too much into detail on the promises and pitfalls of some of the studies, on their methodological strengths and weaknesses, and on the consequences for further research because of contradicting empirical findings between studies. Some of the contributions would have benefited by presenting new data regarding their overall topic instead of showing a 'best of' of one's own research in the last couple of years. Nevertheless, the contributions are a good starting point for scholars and practitioners interested in studying political representation, and the careful reader will find many new avenues for further research.

One key strength of the edited volume is the careful composition of the various contributions, which build on each other logically, and where most of the authors trace the connections between different contributions. Most importantly for representational scholars, several authors again emphasise the need for a clear theoretical, conceptual, and empirical distinction between the static conception of 'policy congruence' and its dynamic version of 'policy responsiveness' (see, e.g., the contributions by Tom Louwerse and Rudy B. Andeweg on "Measuring representation: policy congruence", and by Federico Russo on "Responsiveness, the dynamic as- 
pect of representation"). Particularly the discussions on the policy responsiveness of elected representatives, however, fall a little bit short. Undeniable, the authors rightfully argue that elected representatives must react to fast changing economic, societal, or natural conditions induced by external events or even 'shocks'; yet policy responsiveness is often studied by focusing on the extent policies react to changing preferences of the public, measured via opinion polls. To what extent a public's opinion can be influenced or even manipulated by political actors, however, is not thoroughly discussed, even though the last couple of years in the United Kingdom (Brexit) and the United States of America (Trump) impressively demonstrated the importance of taking these political strategies into account.

Overall, this edited volume is empirically and especially theoretically rich and illuminates the fascinating ongoing research on political representation. This edited volume deserves to be part of the scientific canon when teaching political representation to students. The contributions are easily accessible, well-grounded in theory and on top of the state of the art on all aspects of political representation in modern democracies. Important and valuable, this splendid book will be a cornerstone of the scholarship regarding political representation for years to come.

Funding Open Access funding enabled and organized by Projekt DEAL.

Open Access This article is licensed under a Creative Commons Attribution 4.0 International License, which permits use, sharing, adaptation, distribution and reproduction in any medium or format, as long as you give appropriate credit to the original author(s) and the source, provide a link to the Creative Commons licence, and indicate if changes were made. The images or other third party material in this article are included in the article's Creative Commons licence, unless indicated otherwise in a credit line to the material. If material is not included in the article's Creative Commons licence and your intended use is not permitted by statutory regulation or exceeds the permitted use, you will need to obtain permission directly from the copyright holder. To view a copy of this licence, visit http://creativecommons.org/licenses/by/4. $0 /$. 